\title{
Differential effects of the steaming time and frequency for manufactured red Liriope platyphylla on nerve growth factor secretion ability, nerve growth factor receptor signaling pathway and regulation of calcium concentration
}

\author{
SUN IL CHOI ${ }^{1}$, JUN SEO GOO ${ }^{1}$, JI EUN KIM ${ }^{1}$, SO HEE NAM ${ }^{1}$, IN SIK HWANG ${ }^{1}$, HYE RYUN LEE ${ }^{1}$, \\ YOUNG JU LEE ${ }^{1}$, HONG JOO SON ${ }^{1}$, HEE SEOB LEE ${ }^{2}$, JONG SUP LEE ${ }^{3}$, HAK JIN KIM ${ }^{4}$ and DAE YOUN HWANG ${ }^{1}$ \\ ${ }^{1}$ College of Natural Resources and Life Science, Pusan National University, Miryang 627-706; \\ ${ }^{2}$ College of Human Ecology, Pusan National University, Busan 609-735; ${ }^{3}$ Nonghyup Sandong Processing Plant, \\ Miryang 627-706; ${ }^{4}$ School of Biosystem and Biomaterial Science and Engineering, \\ Seoul National University, Seoul 151-921, Republic of Korea
}

Received February 14, 2012; Accepted August 1, 2012

DOI: $10.3892 / \mathrm{mmr} .2012 .1024$

\begin{abstract}
The herb Liriope platyphylla (LP) has been considered to have curative properties for diabetes, asthma and neurodegenerative disorders. To examine the effects of steaming time and frequency of manufactured red LP (RLP) on the nerve growth factor (NGF) secretion ability and NGF receptor signaling pathway, the NGF concentration, cell differentiation, NGF signaling pathway and calcium concentration were analyzed in neuronal cells treated with several types of LPs manufactured under different conditions. The maximum NGF secretion was observed in B35 cells treated with $50 \mu \mathrm{g} / \mathrm{ml}$ LP extract steamed for $9 \mathrm{~h}$ (9-SLP) and with two repeated steps ( $3 \mathrm{~h}$ steaming and $24 \mathrm{~h}$ air-dried) carried out 7 times (7-SALP). No significant changes in viability were detected in any of the cells treated with the various LPs, with the exception of 0-SLP and 0-SALP. In addition, PC12 cell differentiation was induced by treatment with the NGF-containing conditional medium (CM) collected from the RLP-treated cells. The levels of TrkA and extracellular signal-regulated kinase (ERK) phosphorylation in the high affinity NGF receptor signaling pathway were significantly higher in the cells treated with 3-SLP or 1-SALP/3-SALP CM compared with those treated with the vehicle CM. In the low affinity NGF receptor pathway, the expression levels of most components were higher in the 9-, 15- and 24-SALP CM-treated cells compared with the vehicle
\end{abstract}

Correspondence to: Professor Dae Youn Hwang, Department of Biomaterials Science, College of Natural Resources and Life Science, Pusan National University, 50 Cheonghak-ri, Samnangjin-eup Miryang-si, Gyeongsangnam-do 627-706, Republic of Korea E-mail: dyhwang@pusan.ac.kr

Key words: Liriope platyphylla, nerve growth factor, steaming process, signaling pathway, calcium
CM-treated cells. However, this level was significantly altered in cells treated with 3-SALP CM. Furthermore, an examination of the RLP function on calcium regulation revealed that only the LP- or RLP-treated cells exhibited changes in intracellular and extracellular calcium levels. RLP induced a significant decrease in the intracellular calcium levels and an increase in the extracellular calcium levels. These results suggest the possibility that steaming-processed LP may aid in the relief of neurodegenerative diseases through the NGF secretion ability and NGF signaling pathway.

\section{Introduction}

The herb Liriope platyphylla (LP) has been used to treat asthma and inflammation of the bronchi and lungs in oriental medicine (1). LP is found throughout the temperate climate area of the northern hemisphere and is a perennial seed-reproducing plant. In Korea, the leaves of LP remain green all year round and the plant grows in low mountain regions, at altitudes of less than $500 \mathrm{~m}$ above sea level (2). A number of previous studies have reported the preventative effects of LP root extracts on obesity, diabetes, inflammation and neurodegenerative disease (3-7). Among these effects, LP has also exhibited therapeutic potential in human subjects suffering from Alzheimer's disease (AD). In particular, the steroidal saponin, spicatoside A, isolated from LP induces neuritic outgrowth similar to nerve growth factor (NGF) and activates extracellular signal-regulated kinase 1/2 (ERK1/2) and phosphatidylinositol 3-kinase (PI3-kinase)/Akt in PC12 cells (7). In two types of neuronal cells, B35 and C6, 10\% water extracts of LP induced an increase in NGF secretion, PC12 cell differentiation and NGF mRNA expression (8).

Steaming medicinal plants is a process that is commonly used to increase the levels or effectiveness of functional components and cause the chemical transformation of certain constituents (9). The ginseng plant is steamed and its derivatives are administered orally as adaptogens, aphrodisiacs and 
nourishing stimulants, as well as to treat type II diabetes and male sexual dysfunction (10-12). Korean ginseng is found in two forms: Korean white ginseng (KWG, Panax ginseng C.A. Meyer), which is air-dried, and Korean red ginseng (KRG, Ginseng Radix rubra), which is steamed (9). When ginseng is steamed, a number of components, including ginsenosides, acidic polysaccharides and phenolics, are chemically transformed into different molecules. New compounds, including non-saponinpolyaceylene, maltol and amino acids, are also formed $(13,14)$. Recently, red LP (RLP) was produced by the steaming process and its effects on the insulin secretion ability and insulin receptor signaling pathway were examined. The maximum insulin secretion was observed in the INS cells treated with LP extract steamed for $3 \mathrm{~h}$ (3-SLP) and with two repeated steps ( $3 \mathrm{~h}$ steaming and $24 \mathrm{~h}$ air-dried) carried out 9 times (9-SALP) (15). Despite these primary results, no studies have been performed on how RLP affects the NGF secretion ability and NGF receptor signaling pathway to improve neuronal cell functionality in the treatment of neurodegenerative disease.

Therefore, this study examined the effects of the LP steaming time and frequency on the NGF secretion ability and NGF receptor signaling pathways in order to develop a novel therapeutic drug. These results provide a scientific basis for determining the optimal conditions for the LP steaming process when applied to neuronal relative diseases.

\section{Materials and methods}

Preparation of LP and ginseng sample. The roots of LP were collected from plantations in the Miryang area (Korea) and dried in a hot-air drying machine (JSR, Seoul, Korea) at $60^{\circ} \mathrm{C}$. To prepare five extracts at different steaming times (0-, 3-, 9-, 15- and 24-SLP), $200 \mathrm{~g}$ of dry roots were steamed at $99^{\circ} \mathrm{C}$ for $0,3,9,15$ and $24 \mathrm{~h}$, respectively, and air-dried for $24 \mathrm{~h}$ at $70^{\circ} \mathrm{C}$. These steamed roots were reduced to a powder using an electric blender. The water extracts were purified for $2 \mathrm{~h}$ at $100^{\circ} \mathrm{C}$ using circulating extraction equipment (IKA Labortechnik, Staufen, Germany) after adding $200 \mathrm{ml}$ of distilled water. In addition, a solution of the extracts was concentrated to dry pellets in a rotary evaporator (EYELA, Tokyo, Japan) and stored at $-80^{\circ} \mathrm{C}$ until further use. To prepare six extracts with different steaming frequencies (0-, 1-, 3-, 5-, 7- and 9-SALP), the two-step process $(200 \mathrm{~g}$ of dry roots were steamed at $99^{\circ} \mathrm{C}$ for $3 \mathrm{~h}$ and air-dried at $70^{\circ} \mathrm{C}$ for $24 \mathrm{~h}$ ) was carried out for a different number of repetitions $(0,1,3,5,7$ and 9 times, respectively). The roots obtained using these processes were treated with the same procedures to prepare dry pellets (15).

Two types of Korean ginseng (KWG and KRG) were purchased from Cheng-Kwan-Jang in the Korea Ginseng Corp. (Daejon, Korea). These roots were treated with the same procedures described above to prepare dry pellets.

Cell culture. The B35 neuronal cell line, which secretes NGF, and $\mathrm{PC} 12$ pheochromocytoma cell line were obtained from the the Korean Cell Line Bank (Seoul, Korea). The B35 cell line was maintained for 24-36 h in Dulbecco's Modified Eagle's Medium (DMEM, Hyclone, Logan, UT, USA) containing 10\% fetal bovine serum (FBS, Hyclone), $100 \mathrm{IU} / \mathrm{ml}$ of penicillin and $100 \mu \mathrm{g} / \mathrm{ml}$ of streptomycin. The PC12 cells were cultured in
RPMI-1640 (Hyclone) supplemented with 10\% FBS, 100 IU/ $\mathrm{ml}$ of penicillin and $100 \mu \mathrm{g} / \mathrm{ml}$ of streptomycin. The cells were maintained in a humidified incubator at $37^{\circ} \mathrm{C}$ and $5 \% \mathrm{CO}_{2}$.

MTT assay. The B35 cells were seeded at a density of $4 \times 10^{4}$ cells $/ 200 \mu \mathrm{l}$ in 96 -well plates and grown for $24 \mathrm{~h}$ in a $37^{\circ} \mathrm{C}$ incubator. When the cells reached $70-80 \%$ confluence, they were exposed to distilled water (vehicle), various types of LP extracts $(50 \mu \mathrm{g} / \mathrm{ml})$ or two ginseng extracts $(50 \mu \mathrm{g} / \mathrm{ml})$ dissolved in $\mathrm{dH}_{2} \mathrm{O}$ for a further $24 \mathrm{~h}$. Cell proliferation was determined using the tetrazolium compound, MTT (3-[4,5-dimethylthiazol-2-yl]-2,5-diphenyltetrazolium bromide; Sigma-Aldrich, St. Louis, MO, USA). After discarding the supernatants from the vehicle- and extract-treated wells, $200 \mu \mathrm{l}$ of fresh DMEM and $50 \mu \mathrm{l}$ of an MTT solution ( $2 \mathrm{mg} /$ $\mathrm{ml}$ in phosphate-buffered saline; PBS) were added to each well. The cells were then incubated in a $37^{\circ} \mathrm{C}$ incubator. The reduction of MTT to insoluble purple formazan dye crystals by the viable cells was evaluated in a $220 \mu 1$ sample recovered after $4 \mathrm{~h}$. The formazan precipitate was dissolved in DMSO and the absorbance in the wells was read directly at $540 \mathrm{~nm}$ using a Soft Max Pro5 spectrophotometer (Molecular Devices, Sunnyvale, CA, USA). The data were analyzed in terms of the cell number versus absorbance, allowing the changes in cell proliferation to be quantified.

ELISA for NGF detection. The levels of NGF in the culture supernatant isolated from the B35 cells, which had been cultured and treated under the same conditions as the MTT assay, were detected using an ultra-sensitive assay and reagents in the NGF ELISA kit (Chemicon International Inc., Temecula, CA, USA). Briefly, the sample and standards were incubated overnight on antibody-coated plates in a plate shaker at $100-150 \mathrm{rpm}$ at $2-8^{\circ} \mathrm{C}$. The wells were then washed four times with a wash buffer, after which the anti-mouse NGF monoclonal antibody $(100 \mu \mathrm{l})$ was added to each of the wells. The plates were then incubated in a shaker for $2 \mathrm{~h}$ at room temperature. The peroxidase-conjugated donkey anti-mouse IgG polyclonal antibody $(100 \mu \mathrm{l})$ was then added to each well and the cells were incubated at room temperature for $2 \mathrm{~h}$. After washing, $100 \mu \mathrm{l}$ of TMB/E substrate was added to each well and the cells were incubated at room temperature for $15 \mathrm{~min}$. The reaction was quenched by the addition of $100 \mu \mathrm{l}$ of a stop solution. The plates were analyzed by evaluating the absorbance at $450 \mathrm{~nm}$ using the same spectrophotometer as for the MTT assay.

Neuritic outgrowth assay. To confirm the NGF ability on cell differentiation, conditional medium (CM) was collected from B35 cells treated with LP extracts $(50 \mu \mathrm{g} / \mathrm{ml})$, which had been processed under a range of conditions for $24 \mathrm{~h}$, and added to the undifferentiated PC12 cells. After 24 h, the cell morphology was observed by optical microscopy and the dendrite length of the PC12 cells was measured using a Leica Application Suite (Leica Microsystems, Heerbrugg, Switzerland).

Western blot analyses. Following treatment of the PC12 cells with various types of $\mathrm{CM}$ for $24 \mathrm{~h}$, the cells were harvested from $100 \mathrm{~mm}$-diameter culture dishes and collected in a PRO-PREP protein extraction solution (INtRON Biotechnology, Seongnam, Korea) containing $1.0 \mathrm{mM}$ phenylmethylsulfonyl fluoride 
(PMSF), $1.0 \mathrm{mM}$ ethylenediamine tetraacetic acid (EDTA), $1 \mu \mathrm{M}$ pepstatin A, $1 \mu \mathrm{M}$ leupeptin and $1 \mu \mathrm{M}$ aprotinin. The resulting mixture was centrifuged for $10 \mathrm{~min}$ at $13,000 \mathrm{rpm}$ at $4^{\circ} \mathrm{C}$. The homogenized proteins were separated for $2 \mathrm{~h}$ at $100 \mathrm{~V}$ by $10 \%$ sodium dodecyl sulfate-polyacrylamide gel electrophoresis and transferred to nitrocellulose membranes over $2 \mathrm{~h}$ at $40 \mathrm{~V}$. The membranes were then incubated with the following primary antibodies to determine the levels of each protein: anti-p75NTR antibody (Cell Signaling Technology, Beverley, MA, USA), anti-RhoA antibody (Cell Signaling Technology), anti-TrkA antibody (Cell Signaling Technology), anti-p-TrkA antibody (Cell Signaling Technology), anti-Akt antibody (Cell Signaling Technology), anti-p-Akt antibody (Cell Signaling Technology), anti-ERK antibody (Santa Cruz Biotechnology, Santa Cruz, CA, USA), anti-p-ERK antibody (Santa Cruz Biotechnology) and anti- $\beta$-actin (Sigma-Aldrich). Each membrane was washed with a buffer $(137 \mathrm{mM} \mathrm{NaCl}$, $2.7 \mathrm{mM} \mathrm{KCl}, 10 \mathrm{mM} \mathrm{NaHPO}$ and $0.05 \%$ Tween-20) and incubated with a 1:1,000 dilution of horseradish peroxidase (HRP)-conjugated goat anti-rabbit IgG antibody at room temperature for $2 \mathrm{~h}$. The membrane blots were developed using an Enhanced Chemiluminescence Reagent Plus kit (Amersham Life Science, Piscataway, NJ, USA).

ELISA for extracellular calcium detection. The extracellular calcium concentration in the culture supernatant isolated from the B35 cells, which had been cultured and treated under the same conditions used in the MTT assay, was detected using the ultra-sensitive assay procedure and reagents in a Calcium colorimetric Assay kit (BioVision Research Products, Milpitas, CA, USA). Briefly, the sample and standards $(50 \mu \mathrm{l})$ were placed in an individual well and $90 \mu 1$ of the Chromogenic reagent and $60 \mu \mathrm{l}$ of the Calcium Assay buffer were added. The plates were then incubated in a shaker at $100-150 \mathrm{rpm}$ for $2 \mathrm{~h}$ at room temperature under light-protection conditions. Following incubation, the plates were analyzed by evaluating the absorbance at $575 \mathrm{~nm}$ using an ELISA reader (VERSA max, micro-reader, Molecular Devices).

Detection of intracellular calcium concentration using fura-2 . The concentration of intracellular calcium was determined by the Grynkiewicz method using fura-2/AM (16). Briefly, the prepared B35 cells were incubated with $0.5 \mu \mathrm{M}$ fura-2/AM (F1221, Invitrogen, Carlsbad, CA, USA) at $37^{\circ} \mathrm{C}$ for $40 \mathrm{~min}$ in fresh serum-free RPMI-1640 medium with continuous stirring. A total of $2 \times 10^{6}$ cells were aliquoted for each assay in Ca-free Locke's solution [154 mM NaCl, $5.6 \mathrm{mM} \mathrm{KCl}, 1.2 \mathrm{mM} \mathrm{MgCl}_{2}$, $5 \mathrm{mM}$ HEPES (pH 7.3), $10 \mathrm{mM}$ glucose and $0.2 \mathrm{mM}$ EGTA]. The fluorescence changes at the dual excitation wavelengths of 340 and $380 \mathrm{~nm}$ and the emission wavelength of $500 \mathrm{~nm}$ were measured and the calibrated fluorescence ratio was translated into calcium concentration.

Statistical analysis. Tests for the significance between the various types of LP- and vehicle-treated groups in B35 cells were carried out using the one-way ANOVA test of variance (SPSS for Windows, Release 10.10, Standard Version, Chicago, IL, USA). Values were reported as the mean \pm SD. $\mathrm{P}<0.05$ was considered to indicate a statistically significant result.

\section{Results}

Effects of RLP treated for different steaming times on the viability and NGF secretion ability of B35 cells. The effects of the steaming time on the viability and NGF secretion of B35 cells was evaluated by determining the cell viability and NGF concentration in B35 cells treated with five types of LPs manufactured for different steaming times $(0,3,9,15$ and $24 \mathrm{~h}$ ). In the case of the ginseng treatment group, the cell viability was slightly lower in the KRG- and KWG-treated cells than the cells treated with the vehicle alone. Among the LP-treated cells, an increase in cell viability was detected only in the 24-SLP-treated cells, whereas a decrease in cell viability was detected in the 0- and 15-SLP-treated groups (Fig. 1A). Results of the NGF ELISA analysis showed that the B35 cells treated with RLP had slightly higher NGF concentrations than the group of cells treated with the vehicle alone. By contrast, the increase in the NGF concentration ratio was greater in the 9-SLP-treated B35 cells than in the other groups. Moreover, the cells treated with KWG and KRG maintained the levels observed in the vehicle-treated cells (Fig. 1B). These results suggest that a steaming time for $9 \mathrm{~h}$ should be considered optimal for increasing the NGF secretion ability of B35 cells. This is consistent with the results of a previous study, which found that 9-SLP induced a maximum increase in insulin secretion (15), although the induction ratio was similar to that observed with 0-SLP to 24-SLP.

Effects of RLP manufactured using different steaming frequencies on the viability and NGF secretion ability of B35 cells. The cell viability and NGF concentration of B35 cells treated with the six types of LPs manufactured under different steaming frequencies $(0,1,3,5,7$ and 9 times) were evaluated to determine the effects of the LP steaming frequency on the NGF secretion ability. The cells treated with KWG and KRG showed slightly lower levels of viability than the vehicle-treated cells. Among the LP-treated cells, the lowest viability was observed in the B35 cells treated with 0-SALP. The B35 cells treated with other forms of SALP showed similar or slightly higher viability than the vehicle-treated group (Fig. 1C). However, the NGF concentrations were significantly higher in the B35 cells treated with 7-SALP, whereas a similar level was maintained for the vehicle-treated cells in the cells treated with 0-, 1 and 3-SALP. The 5- and 9-SALP-treated cells maintained the intermediate level of NGF concentrations (Fig. 1D). These results show that 7-SALP is able to induce a maximum increase in NGF secretion ability in B35 cells.

\section{Effect of RLP manufactured for different steaming times and frequencies on the differentiation of PC12 cells. NGF secreted from neuronal cells induced a cell differentiation through the NGF receptors TrkA and $p 75^{\mathrm{NTR}}(17,18)$. To determine whether NGF secreted from B35 cells induced undifferentiated PC12 cells, the length of the PC12 cells was observed following treatment with $\mathrm{CM}$ collected from the $\mathrm{B} 35$ cells treated with the five types of LPs manufactured for different steaming times $(0,3,9,15$ and $24 \mathrm{~h})$ and steaming frequencies $(0,1,3,5$, 7 and 9 times). For the different steaming times, the length of the $\mathrm{PC} 12$ cells was increased significantly in the supernatants treated with all types of SALP as well as the supernatants}


A

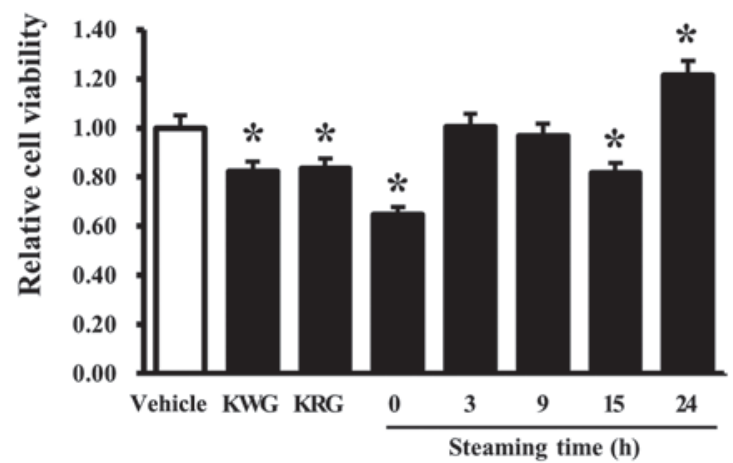

C

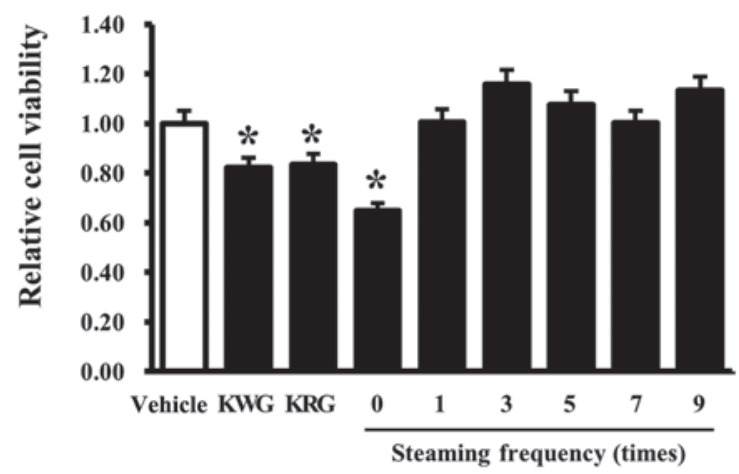

B

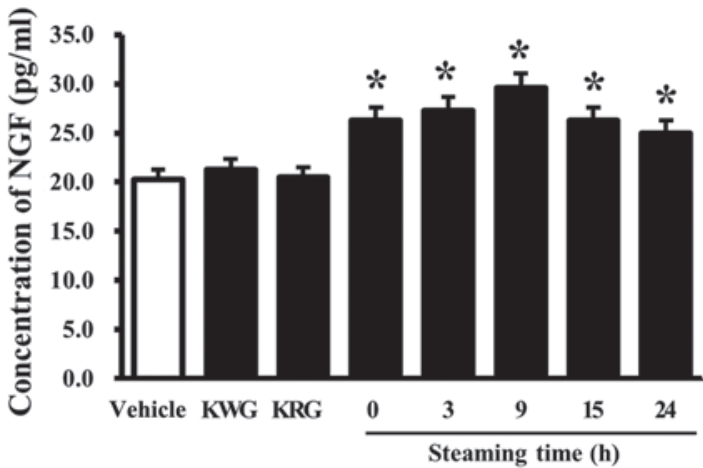

D

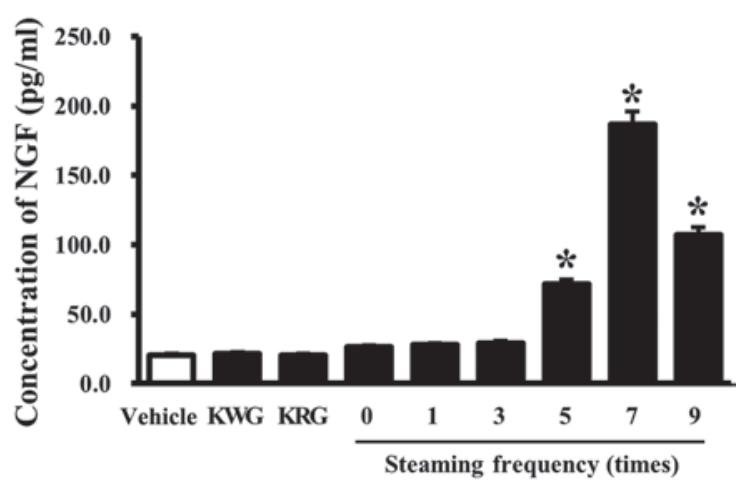

Figure 1. Effects of RLP manufactured for different steaming times and frequencies on the cell viability and NGF secretion in B35 cells. The cells were cultured with one of the different extracts manufactured under (A and B) different times and (C and D) frequencies. (A and C) The cell viability was measured using an MTT assay. The culture supernatants were collected from each of the cells. (B and D) The NGF concentration in the supernatant was measured using an anti-NGF ELISA kit. The data are reported as the mean $\pm \mathrm{SD}$ of three experiments. ${ }^{*} \mathrm{P}<0.05$ is the significance level relative to the vehicle-treated group. RLP, red Liriope platyphylla; NGF, nerve growth factor; KWG, Korean white ginseng; KRG, Korean red ginseng.

treated with ginseng compared with the supernatant treated with the vehicle. By contrast, the ratio of the increase differed according to the group examined (Fig. 2A and B). In the case of different steaming frequencies, the greatest length of PC12 cells was detected in the PC12 cells treated with the 7-SALP supernatant, followed by the PC12 cells treated with 9-, 5- and 1-SALP (Fig. 2A and B). Therefore, the NGF secreted from B35 cells following treatment with the LPs manufactured under the different conditions was able to induce the differentiation of $\mathrm{PC} 12$ cells.

Effect of RLP manufactured for different steaming times and frequencies on the NGF receptor TrkA signaling pathway. The secreted NGF transduced the signal into the cytosol by binding the two types of NGF receptor located on the cell membrane. Of the two types of receptors, the high affinity receptor, TrkA, is capable of inducing neuritic outgrowth via the Akt and ERK signaling pathways (19). Therefore, this study examined the effects of several types of CM collected from B35 cells on the NGF receptor TrkA signaling pathway. In an analysis of the steaming time effects, the phosphorylation of TrkA was increased by the downregulation of unphosphorylated TrkA in the group treated with 3- and 9-SLP CM, whereas the level of TrkA phosphorylation was maintained in the group treated with 15- and 24-SLP CM (Fig. 3A and B). The alteration of ERK or Akt protein phosphorylation was then detected in the cells treated with several types of CM to determine which protein was involved in the signaling pathway activated by
TrkA activation. A significant change in phosphorylation was detected only in the ERK protein. In particular, the level of ERK phosphorylation was higher in the cells treated with 3and 24-SLP CM than the cells treated with the vehicle CM (Fig. 3A and D). By contrast, the level of Akt phosphorylation was maintained in the cells treated with most of the LP CMs, with the exception of 24-SLP CM (Fig. 3A and C).

Similar results were obtained in an analysis of the steaming frequency. The level of TrkA phosphorylation was higher in the cells treated with 1-, 3- and 9-SALP CM due to the downregulation of the unphosphorylated TrkA protein compared with the vehicle CM (Fig. 4A and B). In the downstream TrkA signaling pathway, the pattern of ERK phosphorylation was similar to that of TrkA phosphorylation. The cells treated with 1- and 3-SALP CM showed a higher level of ERK phosphorylation than the cells treated with the vehicle CM (Fig. 4A and D), whereas, the level of Akt phosphorylation did not show any significant changes (Fig. 4A and C). These results suggest that the steaming time and frequency are able to induce the ability of LP to activate the NGF receptor TrkA signaling pathway. In particular, the LP steamed for $3 \mathrm{~h}$ and for 3 different times was found to be the most appropriate formulation for activating the NGF receptor TrkA signaling pathway.

Effect of RLP manufactured for different steaming times and frequencies on the NGF receptor $p 75^{N T R}$ signaling pathway. The effects of LP manufactured for different steaming times and frequencies on the signaling pathway of the NGF receptor 
$\mathbf{A}$
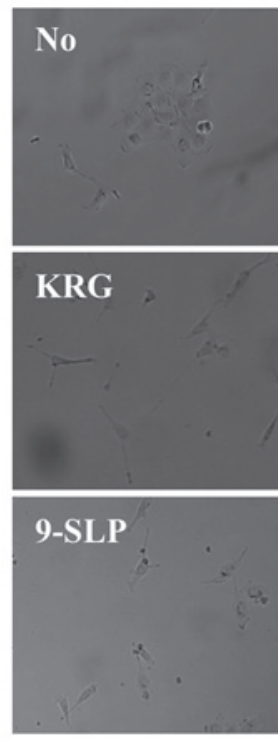

C
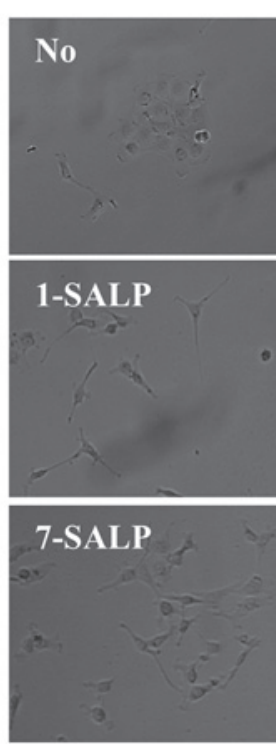
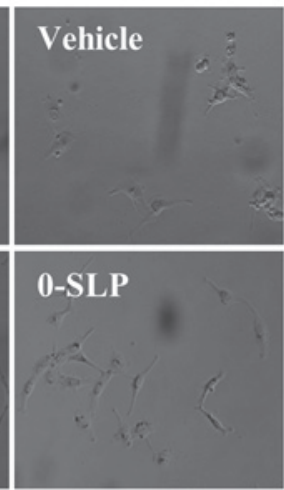

15-SLP
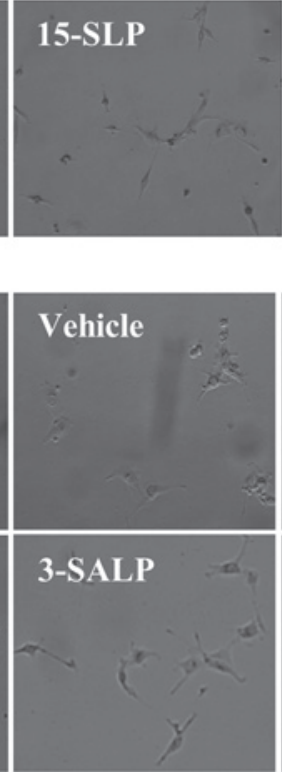

9-SALP

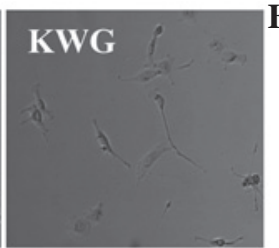

3-SLP

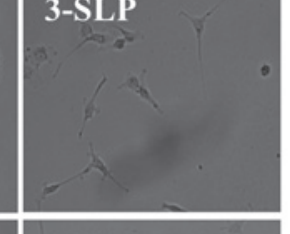

24-SLP

B

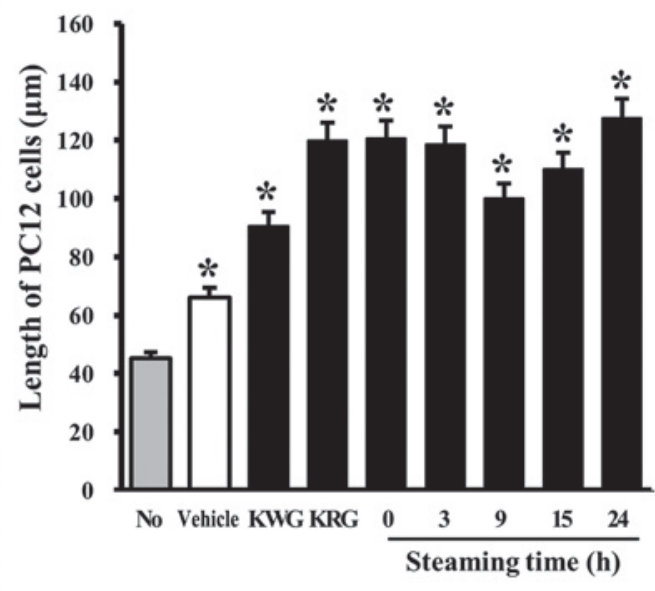

D 180

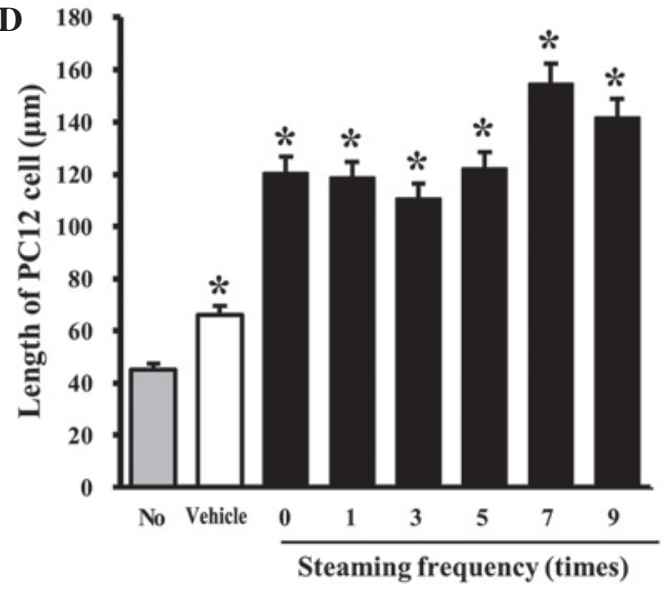

Figure 2. Optical microscopy images of PC12 cells treated with various types of conditional medium collected from B35 cells stimulated with several types of LP manufactured for (A and B) different times and (C and D) frequencies. The vehicle-treated cells were treated with DMSO using the dissolving agents of four compounds. The cell morphology was viewed at a magnification of x20. LP, Liriope platyphylla; KWG, Korean white ginseng; KRG, Korean red ginseng; SLP, steamed LP; SALP, steamed and air-dried LP.

$\mathrm{p} 75^{\mathrm{NTR}}$ as a low affinity receptor for NGF were examined. The level of $\mathrm{p} 75^{\mathrm{NTR}}$ expression was higher in most groups treated with different CM than in the group treated with the vehicle CM. In particular, the maximum level was detected in the groups treated with 9-, 15- and 24-SLP CM (Fig. 5A and B). In addition, the expression of the $\mathrm{p} 75^{\mathrm{NTR}}$ downstream component, RhoA, was significantly higher in the cells treated with 9-, 15- and 24-SLP CM, whereas the level was lower in the cells treated with 0- and 3-SLP CM (Fig. 5A and B). These patterns of protein expression were also observed with the apoptosisrelated proteins, Bcl-2 and Bax. The levels of Bcl-2 and Bax expression were higher in the cells treated with 3-to 24-SLP $\mathrm{CM}$ than in the cells treated with the vehicle or 0-SLP CM (Fig. 5A, D and E).

An analysis of the effects of the steaming frequency revealed a constant level of $\mathrm{p} 75^{\mathrm{NTR}}$ expression but a higher level than the cells treated with the vehicle CM (Fig. 6A and B). However, the level of RhoA expression was higher only in the cells treated with 3-, 5-, 7- and 9-SALP CM than in the vehicle-treated cells, but was lower in the cells treated with 0 - and 1-SALP CM (Fig. 6A and C). Furthermore, the final components of the NGF receptor $\mathrm{p} 75^{\mathrm{NTR}}$ downstream pathway, Bcl-2 and Bax, showed a similar pattern of protein expression. The significant increase in expression was commonly detected in the cells treated with 1- and 3-SALP CM. In the other groups, the levels of Bcl-2 and Bax were decreased or unchanged according to the steaming frequency (Fig. 6A, D and E). These results show that the steaming time and frequency of LP are capable of inducing significant changes in the NGF receptor p75 ${ }^{\text {NTR }}$ signaling pathway. In particular, 9-SLP and 3-SALP were considered to be the most appropriate conditions to induce neuronal differentiation. 
A

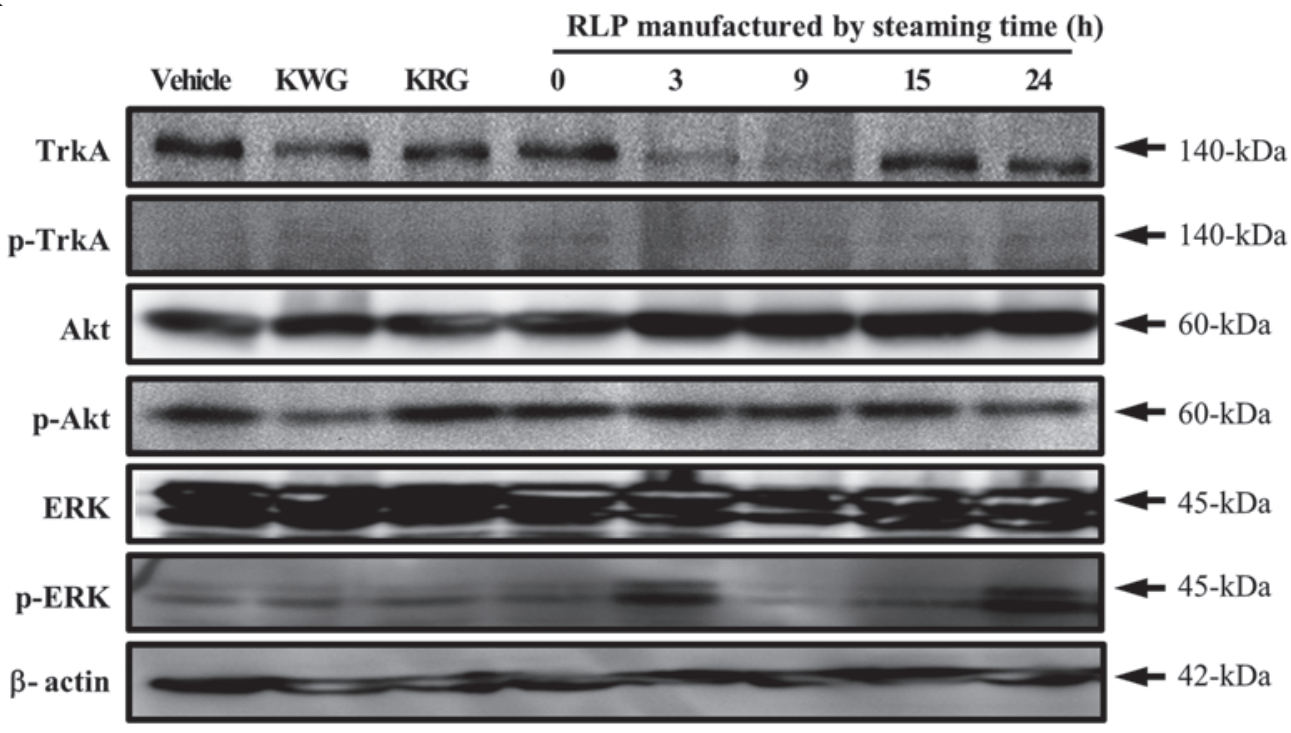

B
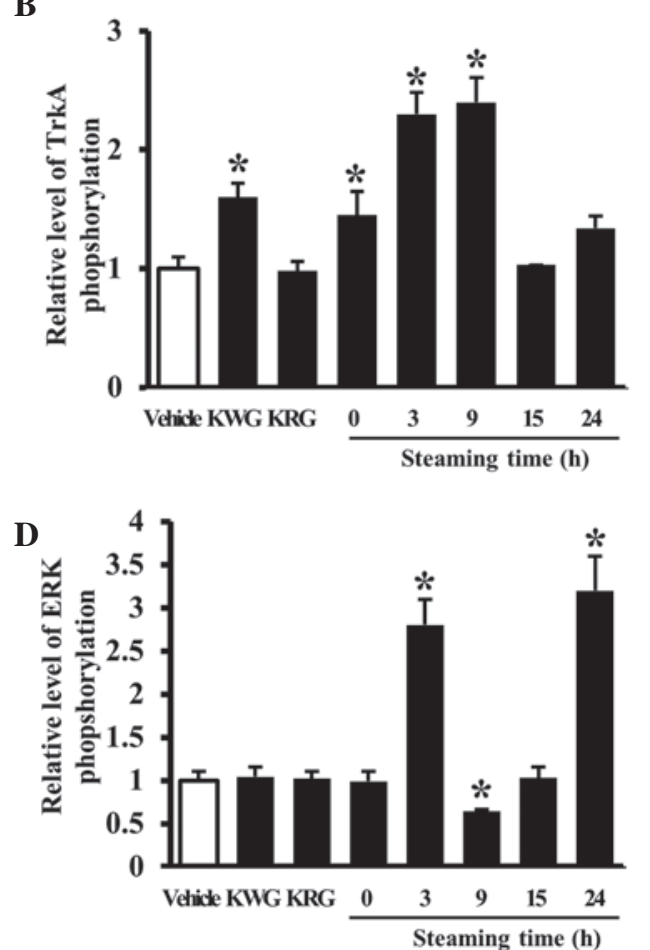

C

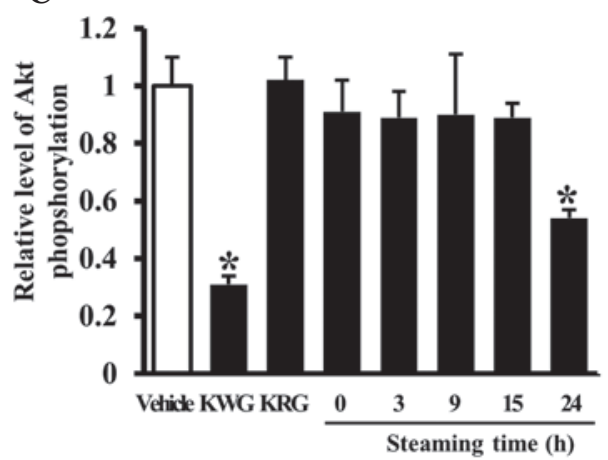

Figure 3. Effects of the RLP manufactured for different steaming times on the downstream signaling pathway of the NGF receptor TrkA signaling pathway by western blotting. The total cell lysates were prepared from PC12 cells treated with the conditioned medium of the vehicle, KWG, KRG and five different LPs prepared under different steaming conditions, as described in Materials and methods. Protein ( $50 \mu \mathrm{g} / \mathrm{sample})$ was immunoblotted with the antibodies for each protein. Three samples were assayed in triplicate by western blotting. The data are reported as the mean \pm SD. " $\mathrm{P}<0.05$ is the significance level compared with the cells treated with the vehicle conditional medium. RLP, red Liriope platyphylla; NGF, nerve growth factor; KWG, Korean white ginseng; KRG, Korean red ginseng; LP, Liriope platyphylla; ERK, extracellular signal-regulated kinase.

Effect of RLP on the regulation of the calcium concentration. The physical function of neuronal cells is regulated by the entry of extracellular calcium through the voltage- or receptor-gated channels as well as the release of calcium from the endoplasmic reticulum (20). The calcium level was measured in the supernatant of B35 cells treated with various extracts to determine the effect of RLP (7-SALP) on the regulation of the extracellular calcium concentration.
In the control group, a significant change in the extracellular calcium concentration was not detected in the KWG-, KRG- and vehicle-treated cells (Fig. 7F, G and H), whereas, in the LP-treated group, the calcium level was increased by $2 \%$ at $20 \mathrm{~min}$ after the treatment (Fig. 7I). Following the RLP treatment, the extracellular calcium concentration increased markedly ( 2 -fold) at the same point (Fig. 7J). Furthermore, the alternation of intracellular calcium was 
A RLP manufactured by steaming frequency (times)
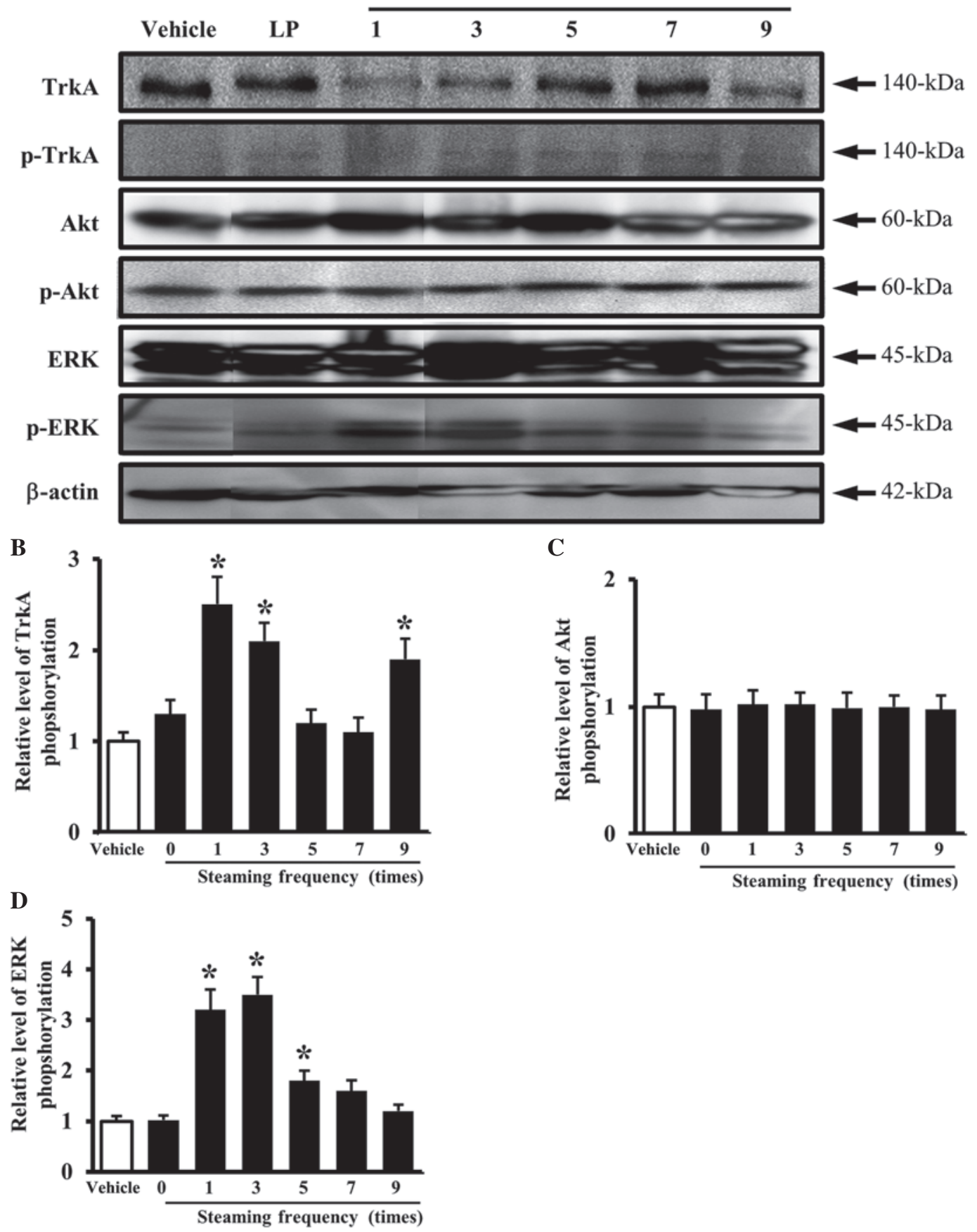

Figure 4. Effects of RLP manufactured at different steaming frequencies on the downstream signaling pathway of the NGF receptor TrkA signaling pathway by western blotting. The total cell lysates were prepared from PC12 cells treated with the conditioned medium of the vehicle, KWG, KRG and six different LPs prepared under different steaming conditions, as described in Materials and methods. Protein $(50 \mu \mathrm{g} / \mathrm{sample})$ was immunoblotted with the antibodies for each protein. Three samples were assayed in triplicate by western blotting. The data are reported as the mean $\pm \mathrm{SD}$. ${ }^{*} \mathrm{P}<0.05$ is the significance level compared with the cells treated with the vehicle conditional medium. RLP, red Liriope platyphylla; NGF, nerve growth factor; KWG, Korean white ginseng; KRG, Korean red ginseng; LP, Liriope platyphylla; ERK, extracellular signal-regulated kinase.

similar to the patterns of extracellular calcium concentration when the B35 cells were treated with the compounds KWG, KRG, LP and RLP. The KWG-, KRG- and vehicle-treated cells did not exhibit a significant change in the intracellular calcium concentration (Fig. 7A-C). The intracellular calcium concentration was markedly decreased in RLP-treated cells, although a slight decrease was detected in LP-treated cells (Fig. 7D and E). Therefore, RLP may induce an increase in the extracellular calcium concentration and a decrease in the intracellular calcium concentration.

\section{Discussion}

Neurotrophic factors are proteins that are produced and released by astrocytes in the brain and periphery. They support the survival of neuronal cells and also contribute to the growth 
A

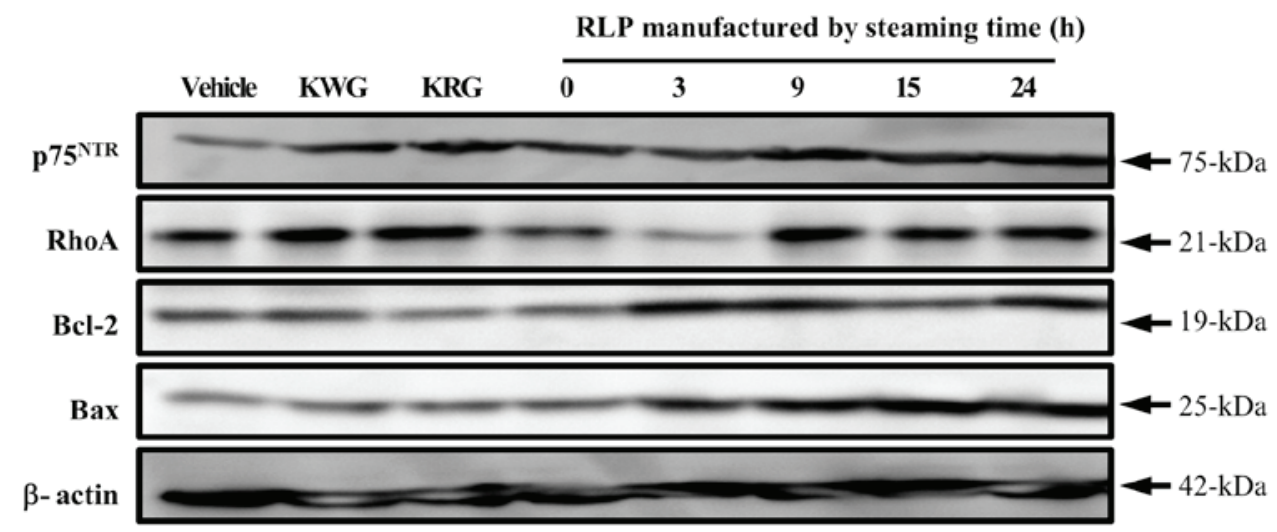

B

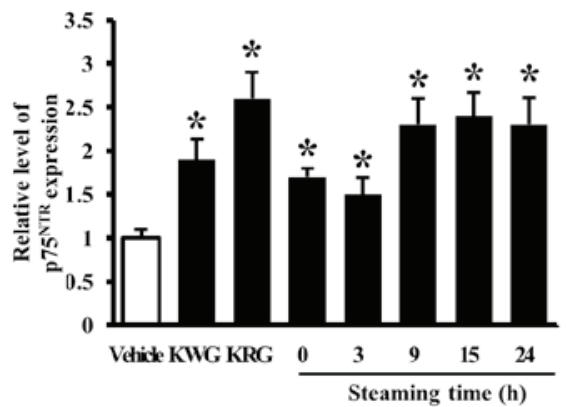

D

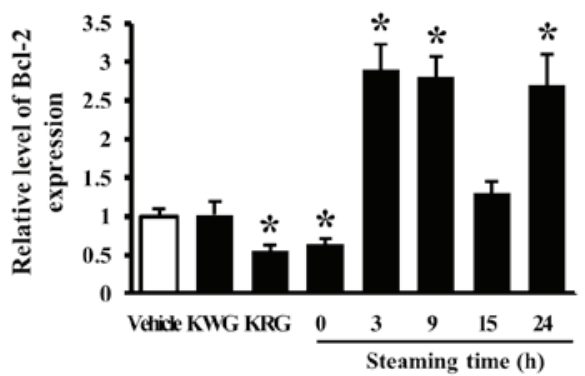

C

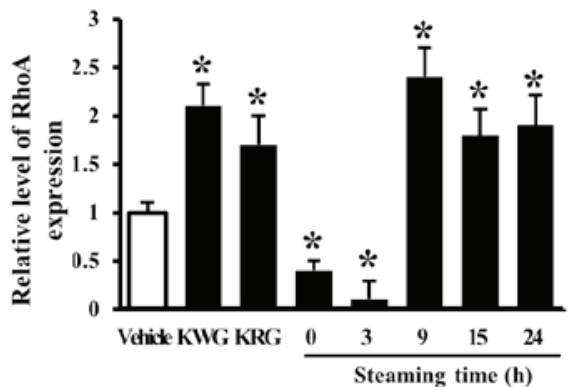

E

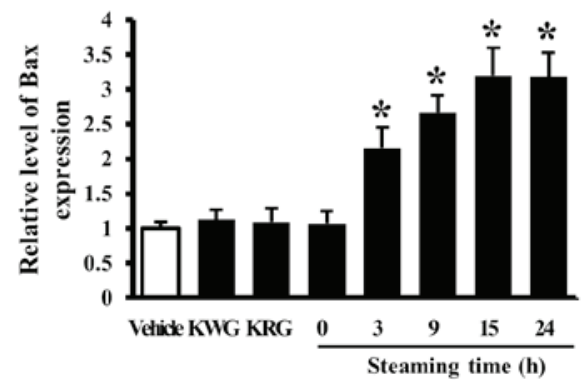

Figure 5. Effects of the RLP manufactured for different steaming times on the downstream signaling pathway of the NGF receptor p75 ${ }^{\mathrm{NTR}}$ signaling pathway by western blotting. The total cell lysates were prepared from the PC12 cells treated with the conditional medium of the vehicle, KWG, KRG and five different LPs prepared under different steaming conditions, as described in Materials and methods. Protein $(50 \mu \mathrm{g} / \mathrm{sample})$ was immunoblotted with the antibodies for each protein. Three samples were assayed in triplicate by western blotting. The data are reported as the mean $\pm \mathrm{SD}$. " $\mathrm{P}<0.05$ is the significance level compared with the cells treated with the vehicle conditional medium. RLP, red Liriope platyphylla; NGF, nerve growth factor; KWG, Korean white ginseng; KRG, Korean red ginseng; LP, Liriope platyphylla.

and differentiation of neurons (21). Among the neurotrophic factors, NGF is a member of the neurotrophic factors family and plays a role in the growth, maintenance and survival of nerve cells. In particular, NGF is critical for axonal growth and the survival of sympathetic and sensory neurons $(22,23)$. NGF has powerful beneficial effects on the damaged or dying neurons which are observed in neurodegenerative disorders, including Alzheimer's disease and dementia, in that elevating the levels of the appropriate neurotrophic factor may aid the restoration of the health and vitality of injured neurons. However, NGF is not used for medical applications since this molecule cannot penetrate the blood-brain barrier owing to its large molecular weight and susceptibility (24). Therefore, a number of studies have focused on the identification of novel agents that increase the level of NGF secretion or enhance the activity of NGF. This study examined the effects of the steaming time and frequency of manufactured RLP on the NGF secretion ability and the NGF receptor signaling pathway to develop a novel agent increasing NGF secretion. As shown in Fig. 1, 7-SALP under various steaming frequencies fully induced NGF secretion without damaging the cell viability.

Several studies have reported a correlation between LP and neuritic outgrowth. C6 and astrocyte cells were incubated with the butanol fraction of LP for $24 \mathrm{~h}$ and the resulting media were then added to PC12 cells, which exhibited neuritic outgrowth as a result. Neuritic outgrowth was increased significantly in a dose-dependent manner and blocked using an NGF antibody and an inhibitor of protein kinase (6). The results from the present study were similar to the results from the butanol fraction. In this study, the maximum length of $\mathrm{PC} 12$ cells was observed in the cells treated with 7-SALP CM, although most conditions for the steaming process induced the neuritic outgrowth of PC12 
A

\section{RLP manufactured by steaming frequency (times)}

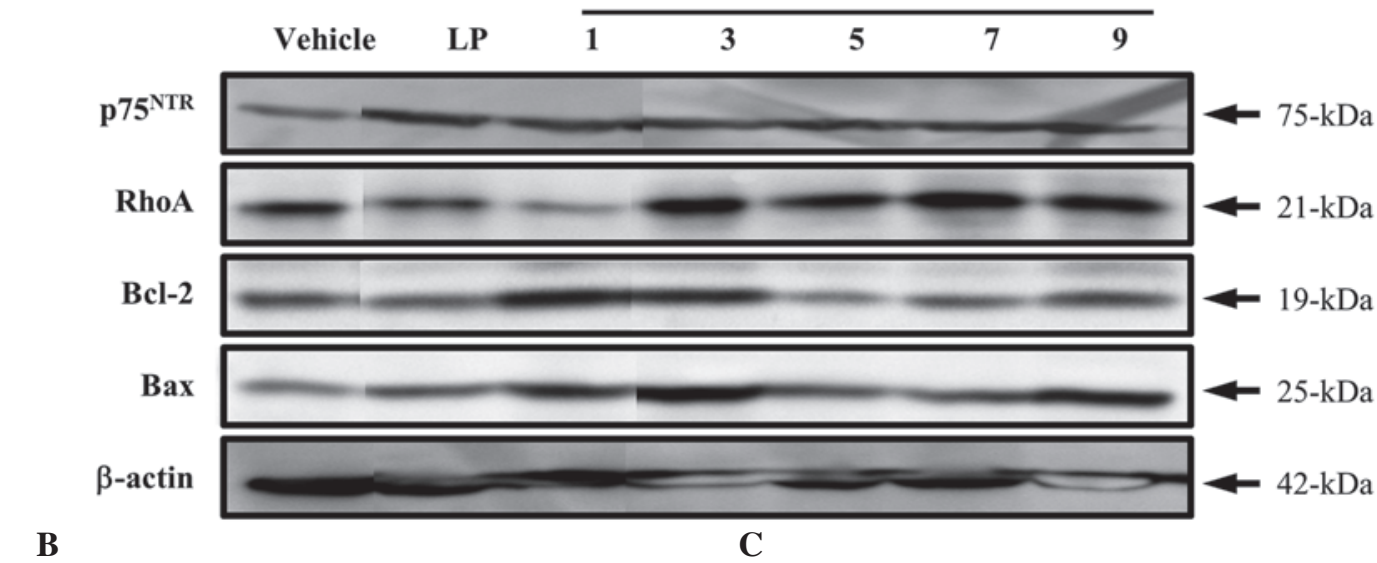

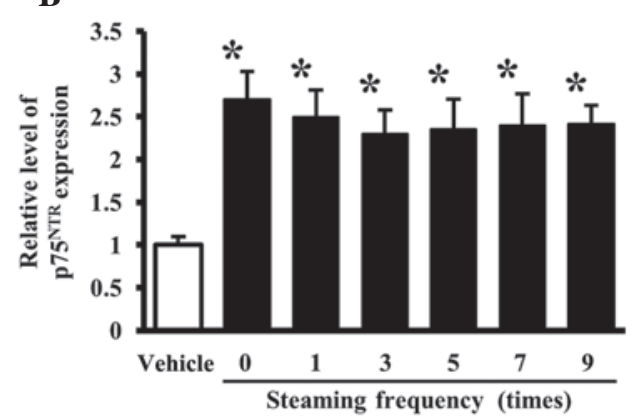

D

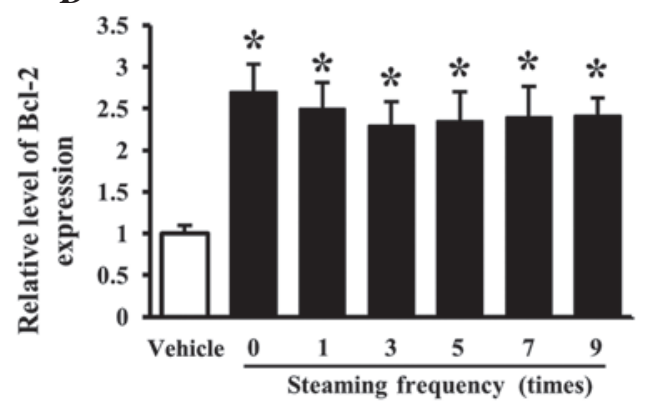

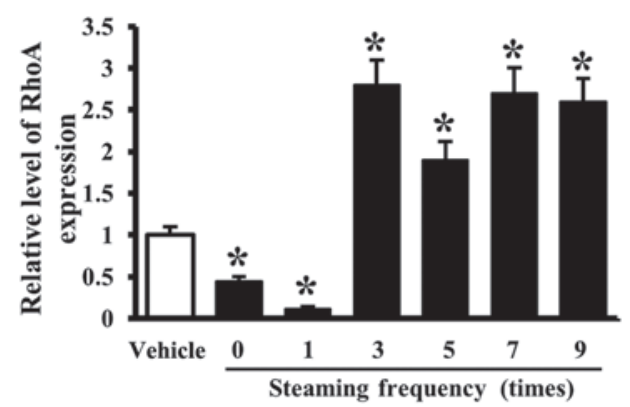

$\mathbf{E}$

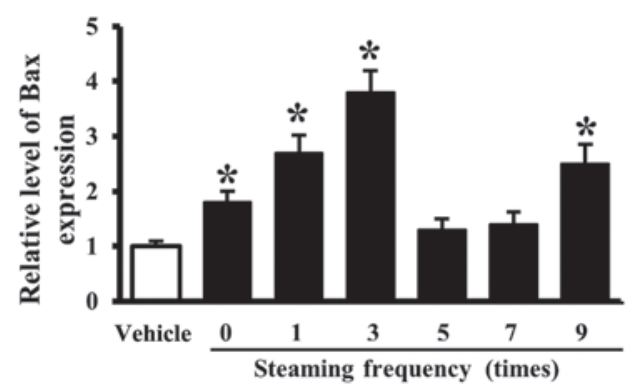

Figure 6. Effects of the RLP manufactured using different steaming frequencies on the downstream signaling pathway of the NGF receptor p75 ${ }^{\mathrm{NTR}}$ signaling pathway by western blotting. The total cell lysates were prepared from PC12 cells treated with the conditional medium of the vehicle, KWG, KRG and six different LPs prepared under different steaming conditions, as described in Materials and methods. Protein (50 $\mu \mathrm{g} / \mathrm{sample})$ was immunoblotted with the antibodies for each protein. Three samples were assayed in triplicate by western blotting. The data are reported as the mean \pm SD. ${ }^{*} \mathrm{P}<0.05$ is the significance level compared with the cells treated with the vehicle conditional medium. RLP, red Liriope platyphylla; LP, Liriope platyphylla; KWG, Korean white ginseng; KRG, Korean red ginseng.

cells. Spicatoside A, a steroid saponin isolated from LP, induced the neuritic outgrowth of PC12 cells similar to NGF (50 ng/ ml) (7). Nevertheless, this study focused not on mimicking the effect of NGF, but on the NGF secretion ability.

Generally, the steaming process induced a chemical transformation or the formation of novel compounds according to the conditions. The steamed ginseng was manufactured by steaming raw ginseng at $98-100^{\circ}$ for $2-3 \mathrm{~h}$, although the steaming process was repeated under several conditions (9). The present study examined the optimal conditions for the LP steaming process on the NGF secretion ability. Of the four steaming times, the maximum NGF secretion was observed in the cells treated with LP, which had been steamed for $9 \mathrm{~h}$ (Fig. 2B), whereas, there was little difference between the maximum and minimum levels of secretion. Furthermore, this study determined the optimal frequency of the steaming process at a 3 -h steaming time. The highest NGF concentra- tions were detected in the cells treated with LP steamed 7 times (Fig. 2D). Therefore, the increase in NGF secretion induced by a treatment with steamed LP might be induced by the component changes caused by the steaming process.

There is ethnopharmacological evidence suggesting that KWG and KRG have regulatory effects on NGF secretion. However, most studies have focused on KWG and only one study has examined the effect of KRG, which is manufactured by a steaming process (25-27). In a study using KRG, administration of estradiol valerate was found to induce a significant increase in NGF protein and NGF mRNA in the ovaries of polycystic ovary-induced rats. These levels were decreased by administering a KRG extract (28). In this study, the steaming process induced a different effect from the NGF secretion ability observed under the condition of the LP treatment. NGF secretion was markedly induced by the 9-SLP and 7-SALP treatments. 


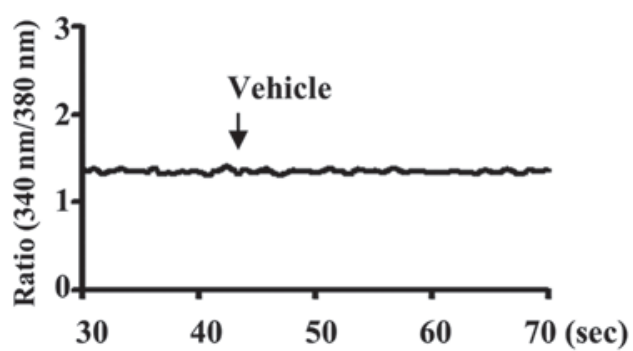

B

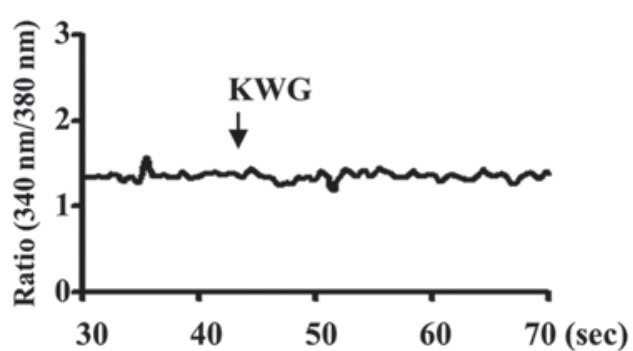

C

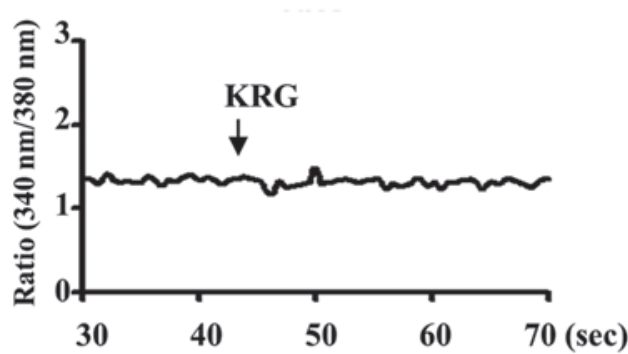

D

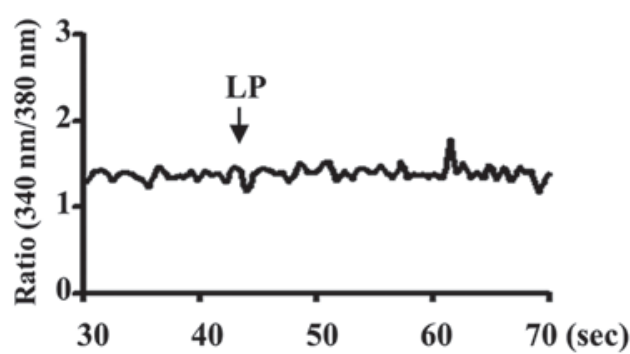

$\mathbf{E}$

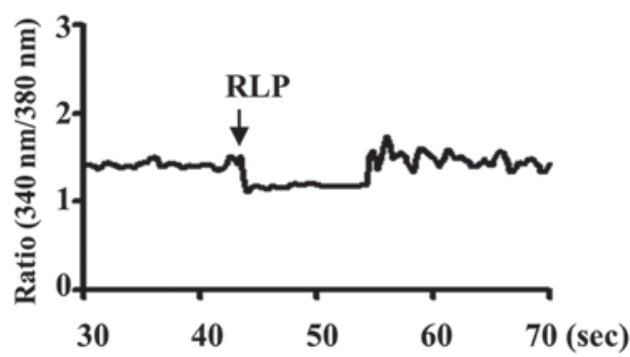

$\mathbf{F}$

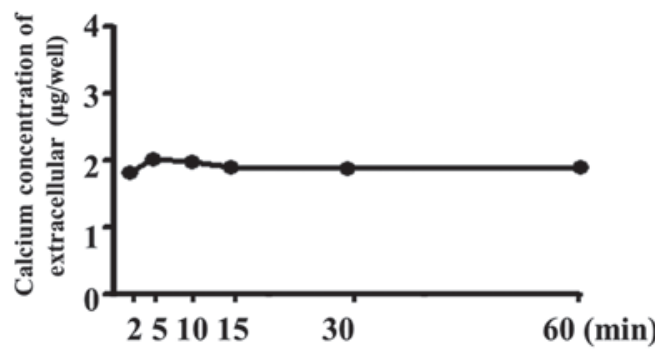

G

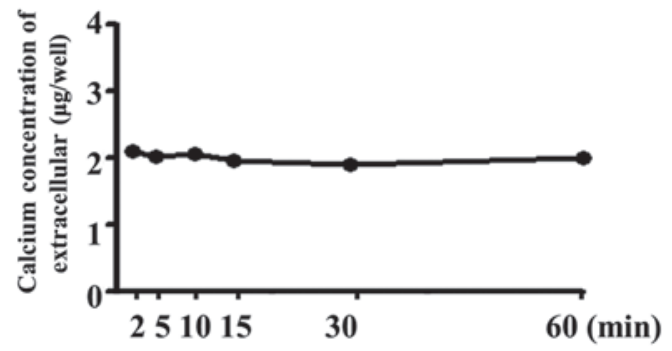

H

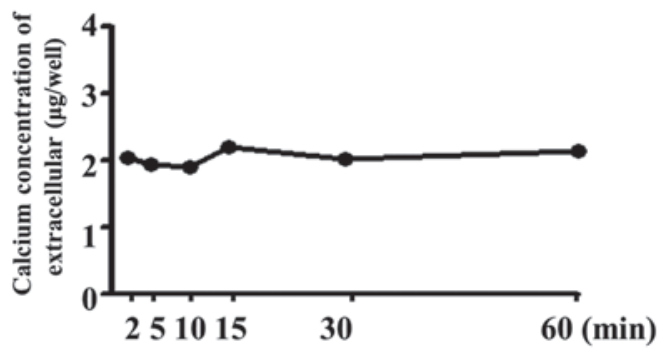

I

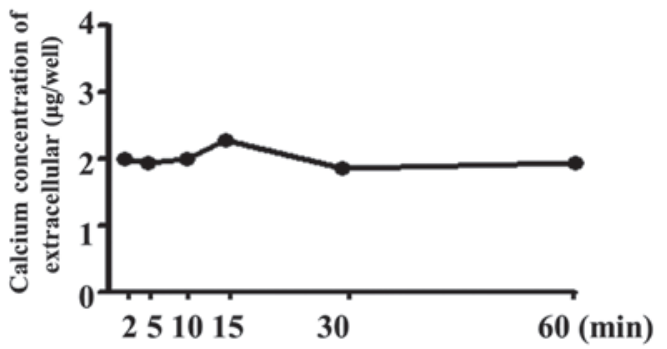

$\mathbf{J}$

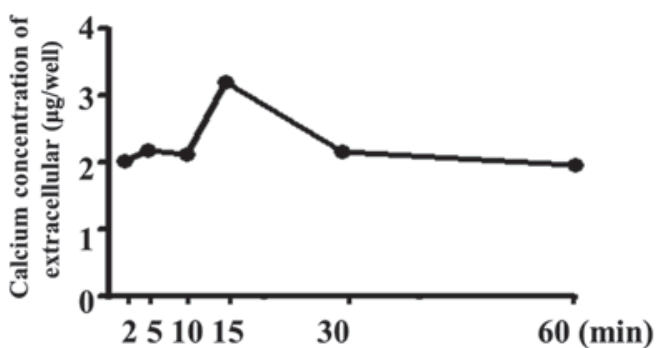

Figure 7. Effect of the RLP treatment on the intracellular and extracellular calcium concentration. (A-E) Fura-2-loaded B35 cells stimulated with $100 \mathrm{mg} / \mathrm{ml}$ of KWG, KRG, LP and RLP (7-SALP) at $43 \mathrm{sec}$. The change in absorbance at 340/380 nm was monitored. (F-J) Following treatment with $50 \mathrm{mg} / \mathrm{ml}$ of each component, the culture supernatants were collected from each group of B35 cells at different times. The extracellular calcium concentration in the supernatant was measured using a calcium colorimetric assay kit. Three samples were assayed in triplicate. RLP, red Liriope platyphylla; LP, Liriope platyphylla; KWG, Korean white ginseng; KRG, Korean red ginseng; SALP, steamed and air-dried LP.

Thus far, there is no evidence that the RLP-CM is able to regulate the signaling pathway of the NGF receptor, although one study reported that spicatoside A activated ERK $1 / 2$ and PI3-kinase/Akt via TrkA sequentially to induce the neuritic process (7). In the present study, LP CM activated TrkA phosphorylation and then their signal stimulated neuritic outgrowth via the ERK pathway. These results showed a similar pattern under the two conditions regardless of the manufacturing methods.

In conclusion, the steam-processed LP induced profound NGF secretion compared with the unsteamed LP under in vitro analysis. Changes in the NGF receptor signaling pathway were observed in the PC12 cells treated with steamprocessed LP. The steam-processed LP may therefore have 
applications as a therapeutic drug in the treatment of neurodegenerative diseases.

\section{Acknowledgements}

This study was supported by grants to Professor Dae Youn Hwang from the Korea Institute of Planning Evaluation for Technology of Food, Agriculture, Forestry and Fisheries (110119-3)

\section{References}

1. Lee YC, Lee JC, Seo YB and Kook YB: Liriopis tuber inhibit OVA-induced airway inflammation and bronchial hyper responsiveness in murine model of asthma. J Ethnopharmacol 101 144-152, 2005

2. Huh MK, Huh HW, Choi JS and Lee BK: Genetic diversity and population structure of Liriope platyphylla (Liliaceae) in Korea. J Life Sci 17: 328-333, 2007.

3. Choi SB, Wha JD and Park S: The insulin sensitizing effect of homoisoflavone-enriched fraction in Liriope platyphylla Wang et Tang via PI3-kinase pathway. Life Sci 75: 2653-2664, 2004.

4. Jeong S, Chae K, Jung YS, Rho YH, Lee J, Ha J, Yoon KH, Kim GC, Oh KS, Shin SS and Yoon M: The Korean traditional medicine Gyeongshingangjeehwan inhibits obesity through the regulation of leptin and PPAR alpha action in OLETF rats. J Ethnopharmacol 119: 245-251, 2008.

5. Kim SW, Chang IM and Oh KB: Inhibition of the bacterial surface protein anchoring transpeptidase sortase by medicinal plants. Biosci Biotechnol Biochem 66: 2751-2754, 2002.

6. Hur J, Lee P, Kim J, Kim AJ, Kim H and Kim SY: Induction of nerve growth factor by butanol fraction of Liriope platyphylla in C6 and primary astrocyte cells. Biol Pharm Bull 27: 1257-1260, 2004.

7. Hur J, Lee P, Moon E, Kang I, Kim SH, Oh MS and Kim SY: Neurite outgrowth induced by spicatoside A, a steroidal saponin, via the tyrosine kinase A receptor pathway. Eur J Pharmacol, 620: 9-15, 2009.

8. Choi SI, Park JH, Her YK, Lee YK, Kim JE, Nam SH, Goo JS, Jang MJ,Lee HS, Son HJ, et al: Effects of water extract of Liriope platyphylla on the mRNA expression and protein secretion of nerve growth factors. Korean J Medicinal Crop Sci 18: 291-297, 2010 (In Korean).

9. Kim K and Kim HY: Korean red ginseng stimulates insulin release from isolated rat pancreatic islets. J Ethnopharmacol 120: 190-195, 2008.

10. Lu JM, Yao Q and Chen C: Ginseng compounds: an update on their molecular mechanisms and medical applications. Curr Vasc Pharmacol 7: 293-302, 2009.

11. Ng TB: Pharmacological activity of sanchi ginseng (Panax notoginseng). J Pharm Pharmacol 58: 1007-1019, 2006.

12. Kiefer D and Pantuso T: Panax ginseng. Am Fam Physician 68: 1539-1542, 2003.
13. Baek NI, Kim DS, Lee YH, Park JD, Lee CB and Kim SI: Ginsenoside Rh4, a genuine dammarane glycoside from Korean red ginseng. Planta Medica 62: 86-87, 1996.

14. Yun TK, Lee YS, Kwon KH and Choi KJ: Saponin contents and anticarcinogenic effects of ginseng depending on types and ages in mice. Zhongguo Yao Li Xue Bao 17: 293-298, 1996.

15. Choi SI, Lee HR, Goo JS, Kim JE, Nam SH, Hwang IS, Lee YJ, Prak SH, Lee HS, Lee JS, et al: Effects of steaming time and frequency for manufactured red Liriope platyphylla on the insulin secretion ability and insulin receptor signaling pathway. Lab Anim Res 27: 117-126, 2011.

16. Grynkiewicz G, Poenie M and Tsien RY: A new generation of $\mathrm{Ca}^{2+}$ indicators with greatly improved fluorescence properties. J Bio Chem 260: 3440-3450, 1985

17. Perini G, Della-Bianca V, Politi V, Della Valle G, Dal-Pra I, Rossi F and Armato U: Role of p75 neurotrophin receptor in the neurotoxicity by $\beta$-amyloid peptides and synergistic effect of inflammatory cytokines. J Exp Med 195: 907-918, 2002.

18. Russo C, Dolcini V, Salis S, Venezia V, Zambrano N, Russo T and Schettini G: Signal transduction through tyrosine-phosphorylated C-terminal fragments of amyloid precursor protein via an enhanced interaction with Shc/Grb2 adaptor proteins in reactive astrocytes of Alzheimer's disease brain. J Biol Chem 277: 35282-35288, 2002

19. Tsui-Pierchala BA and Ginty BB: Characterization of an NGF-P-TrkA retrograde-signaling complex and age-dependent regulation of TrkA phosphorylation in sympathetic neurons. J Neurosci 19: 8207-8218, 1999.

20. Berridge MJ: Neuronal calcium signaling review. Neuron 21: 13-26, 1998.

21. Barres BA and Barde Y: Neuronal and glial cell biology. Curr Opin Neurobiol 10: 642-648, 2000.

22. Levi-Montalcini R: The nerve growth factor: thirty-five years later. EMBO J 6: 1145-1154, 1987.

23. Fiore M, Chaldakov GN and Aloe L: Nerve growth factor as a signaling molecule for nerve cells and also for the neuroendocrine-immune systems. Rev Neurosci 20: 133-145, 2009.

24. Diaz Brinton R and Yamazaki RS: Advances and challenges in the prevention and treatment of Alzheimer's disease. Pharm Res 15: 386-398, 1998

25. Liang W, Ge S, Yang L, Yang M, Ye Z, Yan M, Du J and Luo Z: Ginsenosides Rb1 and Rg1 promote proliferation and expression of neurotrophic factors in primary Schwann cell cultures. Brain Res 1357: 19-25, 2010

26. Yabe T, Tuchida H, Kiyohara H, Takeda T and Yamada H: Induction of NGF synthesis in astrocytes by onjisaponins of Polygala tenuifolia, constituents of kampo (Japanese herbal) medicine, Ninjin-yoei-to. Phytomedicine 10: 106-114, 2003.

27. Pak SC, Kim SE, Oh DM, Shim KM, Jeong MJ, Lim SC, Nah SY, Park SH, Kang SS, Moon CJ, et al: Effect of Korean red ginseng extract in a steroid-induced polycystic ovary murine model. Arch Pharm Res 32: 347-352, 2009.

28. Pak SC, Lim SC, Nah SY, Lee J, Hill JA and Bae CS: Role of Korea red ginseng total saponins in rat infertility induced by polycystic ovaries. Fertil Steril 84: 1139-1143, 2005. 